\title{
Side-Scan Sonar as a Tool for Seafloor Imagery: Examples from the Mediterranean Continental Margin
}

\author{
Alessandra Savini \\ Dept. of Geological Sciences and Geotechnologies, Milano-Bicocca University
}

Italy

\section{Introduction}

The majority of the ocean world's features are being discovered, identified, characterized and imaged by their interactions with sound (Medwin and Blue, 2005). Often a specifically designed sound source is used to learn about the sea and its boundaries (Medwin and Clay, 1998), as in the case of the use of acoustical geophysical devices that provide information about the seafloor and the strata below, transforming the things that we cannot see into numerical data and pictures which give us a model that is able to visually represent the seabed and to outline its physical proprieties and processes (Morang et al., 1997). Such a model, based on the behaviour of the sound pulses and their interaction with water, sediment, rocks and the whole marine environment in which they are emitted, reveals diverse seascapes from shallow water to deep sea and allows us to determine the nature and characteristics of the seabed and additionally, to promote a wide range of practical applications. The research in the marine environment (from oceanography to marine geology, benthic ecology, marine archaeology etc.) now depend heavily on such tools, that provide, as the first step in obtaining the information, the geological framework that can further promote focussed scientific investigations and also better drive seabed utilization for social and economical purposes.

The indirect techniques of investigation used for exploration and study of the submerged environment are different and change according to particular research purposes (Jones, 1999). Generally, acoustical geophysical devices are sound sources that work by transmitting and receiving the sound waves that are reflected, diffracted or scattered off the bottom. They differentiate themselves from each other by the different frequencies employed and thereby the different information that are able to provide about the seabed's proprieties (table 1, Morang et al., 1997). Echo-sounders, side-scan sonar and sub-bottom profilers are the three principal acoustic devices, used to map the seabed in sea exploration programmes, collecting geophysical data that in turn produce morphological and sedimentary models which became instrumental in determining and understanding the geomorphology and the present-day (Holocene) sedimentary processes of the investigated areas. Echo-sounders with a single-beam (Single-Beam Echo-Sounder - SBES) are used for hydrographic (bathymetric) surveys. The Multi-Beam Echo-Sounders (MBES) represent an 
improvement upon the traditional SBES and allow the reconstruction of high resolution 3D views of submarine structures and of topography. The side-scan sonar provides an image (sonograph) from which an understanding of the nature of materials on the seafloor can be drawn (Fish and Carr, 1990; Blondel and Murton, 1997; Blondel, 2009). The sub-bottom profilers are used for examining the high resolution sismo-stratigraphy of the seabed for better interpreting sedimentary processes acting upon the seafloor (Damuth, 1980; Flood 1980).

Imaging of the seabed started in the 1940s, when the first side-scan sonar (SSS) sonograph (hard copy output of sonar data) was recorded (Fish and Carr, 1990). The first sonographs had low resolution and were only able to detect and to image large physical targets on the seafloor, such as big shipwrecks. Then, the rapid developments in acoustic electronics of the 1970s and 1980s led to the production of high-resolution images of the seabed. The SSS system is considered the most relevant acoustic device able to produce images of the seafloor: pursuant to its emission of a pulse of acoustic energy, it amplifies and records the intensity of backscattering from the seafloor, generating the sonograph, that may be considered analogous to a continuous aerial photograph (see Fish and Carr, 1990; Blondel and Murton, 1997 and Blondel, 2009 for details in generating a sonograph).

We can distinguish between high frequency SSS systems, that work roughly between 100 and $1000 \mathrm{kHz}$ (Table 1), and low frequency systems that operate with lower frequencies, down to less than $10 \mathrm{kHz}$ (see Table 1 from Blondel 2009 for the technical specifications of the most common low frequency SSSs).

High frequency SSSs generally work between 25 and $600 \mathrm{~m}$ of operated range and sonograph resolution is range dependent. The choice of the operated range depends on the purposes of the survey and on the environment conditions. A number of sonographs, recorded by high frequency SSS systems during different national and international research programmes, have been recovered and examined in order to produce a representative collection of sonographs collected within the Mediterranean setting. The dataset presented in this chapter was ground-truthed with sediment samples and/ or video data acquired by means of Remotely Operated Vehicles (ROVs). This chapter does not pretend to be an exhaustive list of everything from the Mediterranean seascape, although the sonographs here presented will attempt to outline the most significant features that characterise the Mediterranean continental shelves. A brief description of the side-scan sonar performance and its technical specifications is given in the following paragraph, to help in the understanding of the organization of the data presented, although it is recommended to refer to authoritative books (such as Fish and Carr, 1990; Blondel and Murton, 1997 and Blondel, 2009) for more detailed and precise explanations on the technical aspects related to the acquisition and processing of sonar imagery.

\section{The side-scan sonar as a tool to image the seafloor}

SSS has been defined as an acoustic imaging device used to provide wide-area, highresolution pictures of the seabed (Kenny et al., 2003). This technique was developed by Professor Harold Edgerton and others in the 1960s and is based on the Anti-Submarine Detection Investigation Committee (ASDIC) system built during World War II to detect submarines (Fish and Carr, 1990; Jones, 1999). Its first applications mainly pertained to the 
Side-Scan Sonar as a Tool for Seafloor Imagery:

\begin{tabular}{|c|c|c|c|c|c|c|c|c|c|}
\hline Brand & $\begin{array}{l}\text { Name of } \\
\text { product }\end{array}$ & $\begin{array}{c}\text { Actual } \\
\text { frequency } \\
\text { kHz }\end{array}$ & $\begin{array}{c}\text { Max } \\
\text { range } \mathbf{m}\end{array}$ & $\begin{array}{c}\text { Max depth } \\
\text { rating }\end{array}$ & $\begin{array}{c}\text { Max length } \\
\text { of cable }\end{array}$ & $\begin{array}{c}\text { Horizontal } \\
\text { beam width }\end{array}$ & $\begin{array}{c}\text { Vertical } \\
\text { beam width }\end{array}$ & $\begin{array}{c}\text { Max } \\
\text { horizontal } \\
\text { resolution }\end{array}$ & $\begin{array}{c}\text { Max } \\
\text { operating } \\
\text { speed } \\
\end{array}$ \\
\hline C-MAX Ltd. & $\mathrm{CM} 2$ & $325 / 780$ & 150 & $2000 \mathrm{~m}$ & $3000 \mathrm{~m}$ & $0.2^{\circ}$ & $\begin{array}{l}\text { Full below } \\
\text { horizontal }\end{array}$ & $4 \mathrm{~cm}$ & $1-12 \mathrm{kn}$ \\
\hline $\begin{array}{l}\text { DSME E\&amp; } \\
\text { R Ltd. }\end{array}$ & $\begin{array}{c}\text { SonarBeam S- } \\
150 \text { series }\end{array}$ & 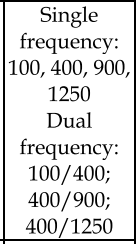 & 500 & $300 \mathrm{~m}$ & $350 \mathrm{~m}$ & $\begin{array}{c}100 \mathrm{kHz}: 1.2^{\circ} \\
400 \mathrm{kHz}: 0.3^{\circ} \\
900 \mathrm{kHz}: 0.3^{\circ} \\
1250 \mathrm{kHz}: \\
0.3^{\circ}\end{array}$ & $\begin{array}{c}100 \mathrm{kHz}: 40^{\circ} \\
400 \mathrm{kHz}: 40^{\circ} \\
900 \mathrm{kHz}: 40^{\circ} \\
1250 \mathrm{kHz}: \\
30^{\circ}\end{array}$ & $\begin{array}{c}\text { Range } 100 \mathrm{~m}- \\
3 \mathrm{~cm}\end{array}$ & $8 \mathrm{kn}$ \\
\hline EdgeTech & 4125 & \begin{tabular}{|c|} 
Choice of \\
$400 / 900$ or \\
$600 / 1600$ \\
\end{tabular} & 150 & $200 \mathrm{~m}$ & $600 \mathrm{~m}$ & $0.2^{\circ}$ & $50^{\circ}$ & $0.5 \mathrm{~cm}$ & $10 \mathrm{kn}$ \\
\hline EdgeTech & 4200 & $\begin{array}{c}\text { Choice of } \\
100 / 400 \text { or } \\
300 / 600 \text { or } \\
300 / 900\end{array}$ & 500 & $\begin{array}{c}2000 \mathrm{~m} \text { (SS); } \\
500 \\
\text { (Allum.) }\end{array}$ & $10000 \mathrm{~m}$ & $0.2^{\circ}$ & $50^{\circ}$ & $1 \mathrm{~cm}$ & $10 \mathrm{kn}$ \\
\hline $\begin{array}{c}\text { GeoAcoustic A } \\
\text { Kongsberg } \\
\text { Company }\end{array}$ & 2094 Digital & $114 / 410$ & $\begin{array}{c}600 \\
(114 \mathrm{kHz}) \\
150 \\
(410 \mathrm{kHz})\end{array}$ & $\begin{array}{c}1000 \mathrm{~m} \\
(2000 \mathrm{~m} \\
\text { optional })\end{array}$ & $6000 \mathrm{~m}$ & $\left|\begin{array}{c}1^{\circ}(114 \mathrm{kHz}) \\
0,3^{\circ}(410 \mathrm{kHz})\end{array}\right|$ & $\begin{array}{l}50^{\circ}(114 \mathrm{kHz}) \\
40^{\circ}(410 \mathrm{kHz})\end{array}$ & $4 \mathrm{~cm}$ & $1-12 \mathrm{kn}$ \\
\hline $\begin{array}{l}\text { Imagenex } \\
\text { Technology } \\
\text { Corp. }\end{array}$ & SportScan & $\begin{array}{c}330 \text { or } \\
330 / 800\end{array}$ & 120 & $30 \mathrm{~m}$ & $60 \mathrm{~m}$ & $0,7^{\circ}$ to $1,8^{\circ}$ & $30^{\circ}$ to $60^{\circ}$ & \begin{tabular}{|c|} 
Range \\
scale $\div 250$ (both \\
side displayed) \\
Range \\
scale $\div 500$ (one \\
side displayed) \\
\end{tabular} & 5 \\
\hline $\begin{array}{c}\text { Imagenex } \\
\text { Technology } \\
\text { Corp. }\end{array}$ & YellowFin & $\begin{array}{c}260 / 330 / 770 \\
\text { nominal }\end{array}$ & 200 & $300 \mathrm{~m}$ & $600 \mathrm{~m}$ & $0,5^{\circ}$ to $2,2^{\circ}$ & $30^{\circ}$ to $75^{\circ}$ & $\begin{array}{c}\text { Range } \\
\text { scale } \div 1000\end{array}$ & 5 \\
\hline IXEA & $\begin{array}{l}\text { SHADOWS } \\
\text { mapping } \\
\text { sonar }\end{array}$ & $100 / 300$ & 300 & $300 \mathrm{~m}$ & $1200 \mathrm{~m}$ & $6^{\circ}$ & $60^{\circ}$ & $\begin{array}{c}15^{\star} 15 \mathrm{~cm} \\
\text { square pixel } \\
\text { constant } \\
\text { across and } \\
\text { along track }\end{array}$ & \\
\hline JW Fisher Mfg. & $\begin{array}{c}\text { SSS - } \\
100 \mathrm{~K} / 600 \mathrm{~K}\end{array}$ & 100 and 600 & $\begin{array}{c}600 \text { and } \\
75 \\
\end{array}$ & $150 \mathrm{~m}$ & $300 \mathrm{~m}$ & $1^{\circ}$ and $1^{\circ}$ & $40^{\circ}$ and $40^{\circ}$ & $6 \mathrm{~cm}$ and $3 \mathrm{~cm}$ & 3 \\
\hline $\begin{array}{c}\text { L-3 Klein } \\
\text { Associated, Inc. }\end{array}$ & $\begin{array}{l}\text { System } 3000 \\
\text { digital side- } \\
\text { scan sonar }\end{array}$ & $100 / 500$ & $\begin{array}{c}600 \\
(100 \mathrm{kHz}) \\
150 \\
(500 \mathrm{kHz})\end{array}$ & $1500 \mathrm{~m}$ & $\begin{array}{c}300 \mathrm{~m} \\
\text { coaxial; } \\
5000 \mathrm{~m} \\
\text { armoured }\end{array}$ & $\begin{array}{c}0,7^{\circ}(100 \mathrm{kHz}) \\
-0,21^{\circ} \\
(500 \mathrm{kHz})\end{array}$ & $40^{\circ}$ & $2,5 \mathrm{~cm}$ & - \\
\hline $\begin{array}{c}\text { L-3 Klein } \\
\text { Associated, Inc. }\end{array}$ & $\begin{array}{c}\text { System } 3900 \\
\text { dual- } \\
\text { frequency } \\
\text { side-scan } \\
\text { sonar } \\
\end{array}$ & $445 / 900$ & $\begin{array}{c}150 \\
(445 \mathrm{kHz}) \\
50 \\
(900 \mathrm{kHz})\end{array}$ & $200 \mathrm{~m}$ & $\begin{array}{l}250 \mathrm{~m} \text { Ltwt. } \\
\text { coaxial cable }\end{array}$ & $\begin{array}{c}0,21^{\circ} \\
(900 \mathrm{kHz})- \\
0,21^{\circ} \\
(445 \mathrm{kHz})\end{array}$ & $40^{\circ}$ & $7,5 \mathrm{~cm}$ & - \\
\hline $\begin{array}{c}\text { L-3 Klein } \\
\text { Associated, Inc. }\end{array}$ & $\begin{array}{l}\text { System } 4000 \\
\text { multibeam } \\
\text { side-scan } \\
\text { sonar }\end{array}$ & 455 & 125 & $200 \mathrm{~m}$ & $\begin{array}{c}250 \mathrm{~m} \text { Ltwt. } \\
\text { coaxial cable; } \\
900 \mathrm{~m} \\
\text { armoured }\end{array}$ & $\begin{array}{c}\text { Dynamically } \\
\text { focused, } 40^{\circ} \\
\text { Vertical, tilted } \\
20^{\circ} \text { down }\end{array}$ & $40^{\circ}$ & \begin{tabular}{|c|} 
Along track \\
$20 \mathrm{~cm} @ 75 \mathrm{~m}$, \\
$30 \mathrm{~cm} @ 125 \mathrm{~m}$ \\
(across track) \\
determined by \\
selected pulse \\
length (from \\
$3.75 \mathrm{~cm}$ to $15 \mathrm{~cm}$ ) \\
\end{tabular} & - \\
\hline $\begin{array}{c}\text { L-3 Klein } \\
\text { Associated, Inc. }\end{array}$ & $\begin{array}{c}\text { Klein } \\
\text { Hydrochart } \\
5000\end{array}$ & 455 & 250 & - & - & & $0.4^{\circ}$ & $\begin{array}{c}10 \mathrm{~cm} \text { at } 38 \mathrm{~m}, \\
20 \mathrm{~cm} \text { at } 75 \mathrm{~m}, \\
\text { increasing to } \\
36 \mathrm{~cm} \text { at } 150 \mathrm{~m} \\
\text { and } 61 \mathrm{~cm} \text { at } \\
250 \mathrm{~m}\end{array}$ & - \\
\hline $\begin{array}{c}\text { L-3 Klein } \\
\text { Associated, Inc. }\end{array}$ & \begin{tabular}{|} 
System 5000 \\
V2 Multibeam \\
Side-scan \\
Sonar
\end{tabular} & 455 & 250 & $500 \mathrm{~m}$ & $\left|\begin{array}{c}250 \mathrm{~m} \text { Ltwt. } \\
\text { coaxial cable; } \\
900 \mathrm{~m} \\
\text { armoured }\end{array}\right|$ & $\begin{array}{c}10 \mathrm{~cm} \text { along } \\
\text { track or } 20 \mathrm{~cm} \\
\text { across track - } \\
\text { focused }\end{array}$ & Nominal $40^{\circ}$ & $\begin{array}{c}10 \mathrm{~cm} \text { at } 38 \mathrm{~m}, \\
20 \mathrm{~cm} \text { at } 75 \mathrm{~m}, \\
\text { increasing to } \\
36 \mathrm{~cm} \text { at } 150 \mathrm{~m} \\
\text { and } 61 \mathrm{~cm} \text { at } \\
250 \mathrm{~m}\end{array}$ & 2 to $10 \mathrm{kn}$ \\
\hline
\end{tabular}




\begin{tabular}{|c|c|c|c|c|c|c|c|c|c|}
\hline $\begin{array}{c}\text { Systems } \\
\text { Engineering } \\
\text { \&amp; } \\
\text { Assessment Ltd. }\end{array}$ & SWATHplus & $\begin{array}{c}117 / 234 / \\
468\end{array}$ & $\mid \begin{array}{c}350 \\
(117 \mathrm{kHz}) ; \\
200 \\
(234 \mathrm{kHz}) ; \\
90 \mathrm{~m} \\
(468 \mathrm{kHz})\end{array}$ & $1000 \mathrm{~m}$ & 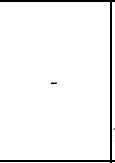 & $\begin{array}{c}1,7^{\circ} \\
(117 \mathrm{kHz}) \\
1,1^{\circ} \\
(234 \mathrm{kHz}) \\
1,1^{\circ}(468 \mathrm{kHz})\end{array}$ & $240^{\circ}$ & $\mid \begin{array}{l}5 \mathrm{~cm}(117 \mathrm{kHz}) ; \\
2 \mathrm{~cm}(234 \mathrm{kHz}) ; \\
1 \mathrm{~cm}(468 \mathrm{kHz})\end{array}$ & $6 \mathrm{kn}$ \\
\hline $\begin{array}{c}\text { Tritech } \\
\text { International }\end{array}$ & StarFish $450 \mathrm{~F}$ & 450 & $\begin{array}{l}1 \mathrm{~m} \text { to } \\
100 \mathrm{~m}\end{array}$ & $50 \mathrm{~m}$ & $\begin{array}{c}20 \mathrm{~m} 50 \mathrm{~m} \\
\text { available }\end{array}$ & $1,7^{\circ}$ & $60^{\circ}$ & - & - \\
\hline $\begin{array}{c}\text { Tritech } \\
\text { International }\end{array}$ & StarFish $452 \mathrm{~F}$ & 450 & $\begin{array}{l}1 \mathrm{~m} \text { to } \\
100 \mathrm{~m}\end{array}$ & $50 \mathrm{~m}$ & $\begin{array}{l}20 \mathrm{~m} 50 \mathrm{~m} \\
\text { available }\end{array}$ & $0,8^{\circ}$ & $60^{\circ}$ & - & - \\
\hline $\begin{array}{c}\text { Tritech } \\
\text { International }\end{array}$ & StarFish $990 \mathrm{~F}$ & 1000 & $\begin{array}{c}1 \mathrm{~m} \text { to } \\
35 \mathrm{~m}\end{array}$ & $50 \mathrm{~m}$ & $\begin{array}{l}20 \mathrm{~m} 50 \mathrm{~m} \\
\text { available }\end{array}$ & $0,3^{\circ}$ & $60^{\circ}$ & - & - \\
\hline $\begin{array}{l}\text { Teledyne } \\
\text { Benthos }\end{array}$ & $\begin{array}{c}\text { C3D-LPM } \\
\text { Side-scan } \\
\text { Imaging with } \\
\text { Bathymetry }\end{array}$ & $\begin{array}{c}200 \mathrm{kHz} \\
\text { standard } \\
100 \mathrm{kHz} \\
\text { optional }\end{array}$ & $\begin{array}{c}25-300 \mathrm{~m} \\
(200 \mathrm{kHz}) \\
25-600 \mathrm{~m} \\
(100 \mathrm{kHz})\end{array}$ & $\begin{array}{l}\text { Surface } \\
\text { vessel } \\
\text { mounted }\end{array}$ & $20 \mathrm{~m}$ & $1^{\circ}$ & $100^{\circ}$ & $\begin{array}{c}\text { Side-scan } \\
\text { across track } \\
4,5 \mathrm{~cm} ; \\
\text { Bathymetry } \\
\text { across track } \\
5,5 \mathrm{~cm} \\
\end{array}$ & $10 \mathrm{kn}$ \\
\hline $\begin{array}{l}\text { Teledyne } \\
\text { Benthos }\end{array}$ & $\begin{array}{c}\text { C3D-TOW } \\
\text { Side-scan } \\
\text { Imaging with } \\
\text { Bathymetry }\end{array}$ & $\begin{array}{c}200 \mathrm{kHz} \\
\text { standard } \\
100 \mathrm{kHz} \\
\text { optional }\end{array}$ & $\begin{array}{c}25-300 \mathrm{~m} \\
(200 \mathrm{kHz}) \\
25-600 \mathrm{~m} \\
(100 \mathrm{kHz})\end{array}$ & 3000 & $\begin{array}{c}200 \mathrm{~m} \\
\text { Kevlar; } \\
10000 \mathrm{~m} \\
\text { double } \\
\text { armoured } \\
\text { cable }\end{array}$ & $1^{\circ}$ & $100^{\circ}$ & $\begin{array}{c}\text { Side-scan } \\
\text { across track } \\
4,5 \mathrm{~cm} ; \\
\text { Bathymetry } \\
\text { across track } \\
5,5 \mathrm{~cm} \\
\end{array}$ & $10 \mathrm{kn}$ \\
\hline
\end{tabular}

Table 1. Examples of some of the most common models of high frequency SSS systems and their different technical specifications (data are from a survey of products carried out by Hydro International eburnal and available at http:/ / ww w.hydrointernational.com/ productsurvey).

search for objects on the seabed, subsequent works have led to far-reaching advances in the use of sonar in marine geophysics and geology (see Belderson et al., 1972; McQuillin and Ardus 1977; Blondel and Murton, 1997; Jones 1999 and Blondel, 2009 to get an historical perspective on the evolution of side-scan sonar systems applied to the exploration of the seafloor).

Due to its capacity to provide seabed images, SSS has become an instrumental tool in seafloor mapping, with a number of applications, such as:

- Investigation of seafloor morphology and sediment characteristics (i.e. occurrence of reliefs, depressions, sedimentary structures etc.)

- Map the distribution of marine sediments and even peculiar biocenosis like seagrass meadows, coral banks etc.

- Detect specific targets on the seafloor such as shipwrecks, mines, sunken objects, etc.

- Identify the proper placement of infrastructures (oil drilling, platforms, cables etc.)

- Monitoring the seafloor for environmental applications, such as coastal and deep environment management.

The system typically consists of an underwater transducer connected via a cable to a shipboard recording device. The emitting lobe of sonar energy (narrow in azimuth from the transducer) has a beam geometry that insonifies a wide swath of the seabed, particularly when operated at low frequencies $(<100 \mathrm{kHz})$. The returning echoes from the seafloor are received by the transducers over a short period of time (from a few milliseconds to $1 \mathrm{~s}$ ), amplified on a time-varied gain curve and then transmitted to the recording unit. Most technological advances relate to the control of the phase and amplitude of the emitting sonar signal, and in the precise control of the time-varied gain applied to the return signals. In the case of a non-digital transducer, the analogue signal is converted into a digital format, the proper position for each signal in the final record (pixel by pixel) is calculated and then 
these echoes are printed on electro-sensitive or thermal paper, one scan or line at a time. Modern high (dual) frequency digital SSS devices offer high-resolution images of the seabed on which objects in the order of few centimetres may be detected at a variable range, from a few tens of metres up to $600 \mathrm{~m}$ either side of the tow fish (in this latter case the total swath width is $1200 \mathrm{~m}$ and horizontal resolution can reach less then $100 \mathrm{~cm}$ ).

The sonographs present as grey level (or optionally as colour scale) the local backscattering coefficients. The different backscattering intensities received by the sonar depend on a number of physical (the frequency of the system - which significantly varies from 100 up to $1000 \mathrm{kHz}$ - and other technical configurations), geometric (angle at which the acoustic wave reaches the seafloor) and geological parameters (porosity and roughness of the seafloor that define the acoustic proprieties of the surface sediments in accordance to their physical and chemical nature). A copious literature (see, among others, Jackson and Briggs, 1992; Boyle and Chatiros, 1995; Blondel et al., 1998; Goff et al., 2000; Holland et al., 2000) has been developed to define the dependence of the acoustic backscattering on the different factors mentioned before, providing backscattering models. Nevertheless, no consensus exists on which model is the better one for side-scan sonar backscattering and research is still very active (Blondel and Murton, 1997; Blondel, 2009). Besides, different seabed types can be seen on the sonographs as different textures of the various parts of the image. In an effort to make side-scan sonar interpretation a function of quantitative analysis, a lot of authors (among others see Blondel et al., 1998; Huvenne et al., 2002; Cochrane and Lafferty, 2002) have reported the use of some image texture processing algorithms (i.e. co-occurrence matrix) to discriminate the regions of different seabed types.

Since different seabed types can be seen on the sonographs as different textures on the various parts of the image; the first step of sonograph interpretation consists of the discrimination of the different textures that compose the sonographs that in turn produce the identification of different acoustic facies. This process can be carried out through supervised or unsupervised automatic classification (of image textures) operated by proper software or by human discrimination of different textures, which is often the case, although qualitative interpretations of acoustic imagery are increasingly supported by quantitative analyses of backscatter and by the study of the role that the seafloor plays in its variations (Loiacono et al., 2009). The association of ground-truth information (sediment samples and/ or video recording and still images) to the acoustic facies that have been picked out with both the analysis, provide then aid classification of the seabed.

\subsection{The side-scan sonar performance}

Precision and accuracy of sonographs depend on a number of factors and they are determined according to SSS performance. Defining the SSS performance is thus necessary to understand what SSS can image from the seafloor environments and how. For instance, the resolution is an important feature in sonographs, because it provides the measure of the detail that is possible to detect on the sonograph. The resolution of SSS can be meant in a different way:

- The system resolution: governed by the shape of the acoustic beam and the length of the transmitted pulse (Jones, 1999). So it depends on the three-dimensional distribution of the acoustic energy of the system that affects the size of the footprint. If the side-scan sonar has low frequency sources $(10-30 \mathrm{kHz})$, the sound pulse will be transmitted and received at long range (covering a large area in a short time), but this configuration 
provides lower resolution in the sonographs. If the needs of the survey are for accurate, fine image details, then it is better to use a higher frequency sonar $(100-500 \mathrm{kHz})$, even if the short wavelengths generated cannot be transmitted long distance and thereby limit the usable range. For this reason these kinds of systems are employed mainly on continental shelves. Flemming et al. (1976) well described the characteristic transverse resolution and range resolution of the side-scan sonar systems; they can be meant as across-track footprint and along-track footprint respectively (Blondel and Murton, 1997). Obviously each transducer capability can offer different resolution, depending on the technical specification of each sonar (Table 1) and also the speed of the transducer in the water influences the along-track resolution. Lastly, for each system, the across-track resolution strictly depends on the range setting employed (nowadays, for new models, the along-track resolution can be independent of range).

- The sonograph resolution: governed by the pixel size. Indeed the successive across-track profiles are 'plotted' into sonographs by computation of square picture elements (pixels).

The resolution is not the only parameter that affects the system performance and data quality. The underwater environment (current, density, salinity etc.) can considerably impact the data, and even more importantly, so too can the operator management of the system. Survey vessel course, transducers speed, tow fish altitude above the seabed and the range setting will determine the quality of the sonar data, according to the aim of the survey.

\section{Data and methods}

The data presented here were collected at different sites located on the continental shelf of the Mediterranean sea. Different range settings are presented, illustrating the different resolution capacity of the employed high frequency $(100-500 \mathrm{kHz})$ sonar systems. The sonographs are arranged in three paragraphs, according to their range, for a total of three sections (wide-, medium-, small-range). An additional paragraph discusses some peculiar situations that can occur during a side-scan sonar survey, as noise comes from the underwater environment (e.g. signal generated from other ship propellers and/ or from interference with other acoustic sources, artefacts created by objects or fishes in the water column). In each sonograph, where it is not specified, high levels of backscatter are shown as dark tones. Each section is introduced with an overview on the different types and spatial scale of seafloor features that can be investigated, according to the employed range setting. It is worth noting that the range setting also determines the operational conditions of the survey, because the tow fish must be located at a precise distance above the bottom, approximately equivalent to between $10 \%$ and $20 \%$ of the range. So, the geomorphological setting and the survey environment do not always allow a free choice of the range setting. With complex topography and in a deep environment it is not possible to use narrow range that requires to have the tow fish at a short distance from the bottom (this situation indeed does not guarantee the safety condition of towed equipment), to operate in a deep environment, high frequency SSS must be integrated within AUV or specific ROV. In shallow water we cannot use a wide range, because it is recommended to have more than $10 \%$ of the range setting as a distance above the bottom. Therefore, the range setting not only influences the aim of the survey (because of the associated sonograph resolution), but 
also the depth range in which the survey can be performed, according to the environment condition (Table 2).

\begin{tabular}{|c|c|c|c|l|}
\hline $\begin{array}{c}\text { Range } \\
\text { setting (m) }\end{array}$ & $\begin{array}{l}\text { Optimum } \\
\text { two fish } \\
\text { distance } \\
\text { from the } \\
\text { bottom }\end{array}$ & $\begin{array}{l}\text { Resolution } \\
\text { (m x pixel) }\end{array}$ & Geomorphological setting & Main aims of the survey \\
\hline $\begin{array}{c}\text { From few } \\
\text { metres to } \\
150\end{array}$ & $5-50 \mathrm{~m}$ & $<1$ & $\begin{array}{l}\text { Continental shelf in shallow } \\
\text { water, betw een }-10 \text { and }-30 \\
\text { m up to }-50 \text { m if the } \\
\text { topographic features are } \\
\text { known and without reliefs. }\end{array}$ & $\begin{array}{l}\text { Research of specific target, } \\
\text { such as small shipwrecks, } \\
\text { Monitoring of underw ater } \\
\text { infrastructures, such as } \\
\text { pipelines or other small } \\
\text { structures. }\end{array}$ \\
\hline $150-300$ & $15-30 \mathrm{~m}$ & Ca. 1 & $\begin{array}{l}\text { From } 30 \mathrm{~m} \text { of water depth } \\
\text { down to the shelfbreak. }\end{array}$ & $\begin{array}{l}\text { Meso-scale maps of the } \\
\text { seafloor to represent a } \\
\text { number of environment } \\
\text { features (geological, } \\
\text { sedimentological, } \\
\text { geomorphological, habitat } \\
\text { maps, etc.). }\end{array}$ \\
\hline $300-600$ & $30-60 \mathrm{~m}$ & $>1$ & $\begin{array}{l}\text { From }-40 \mathrm{~m} \text { up to the inner } \\
\text { slope }(600 \mathrm{~m}) .\end{array}$ & $\begin{array}{l}\text { Meso-scale maps of the } \\
\text { seafloor. }\end{array}$ \\
\hline
\end{tabular}

Table 2. Summary of the three main classes of high frequency SSS range settings (from top to bottom: small-, medium and wide-) with indication of the associated sonograph resolution, optimum geomorphological setting and aim of surveys (from Savini, 2004).

\subsection{High frequency SSS imagery through wide-range setting}

SSS surveys through wide-range setting aim to cover wide areas of the seafloor on the outer continental shelf and the upper slope. Range from 300 up to $600 \mathrm{~m}$ are considered, so an operating frequency not higher than $100 \mathrm{kHz}$ should be employed with the sonograph's resolution reaching roughly $1 \mathrm{~m}$ per pixel. Wide-range settings, through high frequency SSS systems, are adopted when medium to small-scale maps of the seafloor must be produced and water depth is more than a minimum of $40 \mathrm{~m}$ (because the distance of the tow fish from the bottom should not be less than the $10 \%$ of the operating range). The outer continental shelf and the upper continental slope are candidate areas to be investigated by wide-range setting, where the roughness of the seafloor can vary a lot, outlining homogeneous seafloors, with a gently sloping shelf-break and muddy bottom, or various types of articulated seabeds with reliefs and/ or depressions of different sizes, rocky outcrops and abrupt changes in slope gradient. If the seafloor morphology is very rough (especially in an active geodynamic context), huge shadows and repeated echoes can characterize the associated sonographs. Geological attributes that can be relevant to map with wide-range setting can be:

- Canyon heads and scarps of different origin and sizes (Fig. 1).

- Rocky outcrops where typical small scale faults and other structural features can be detected. 
- Boulders and/ or masses of different sizes, often associated with failure deposits on the upper slope.

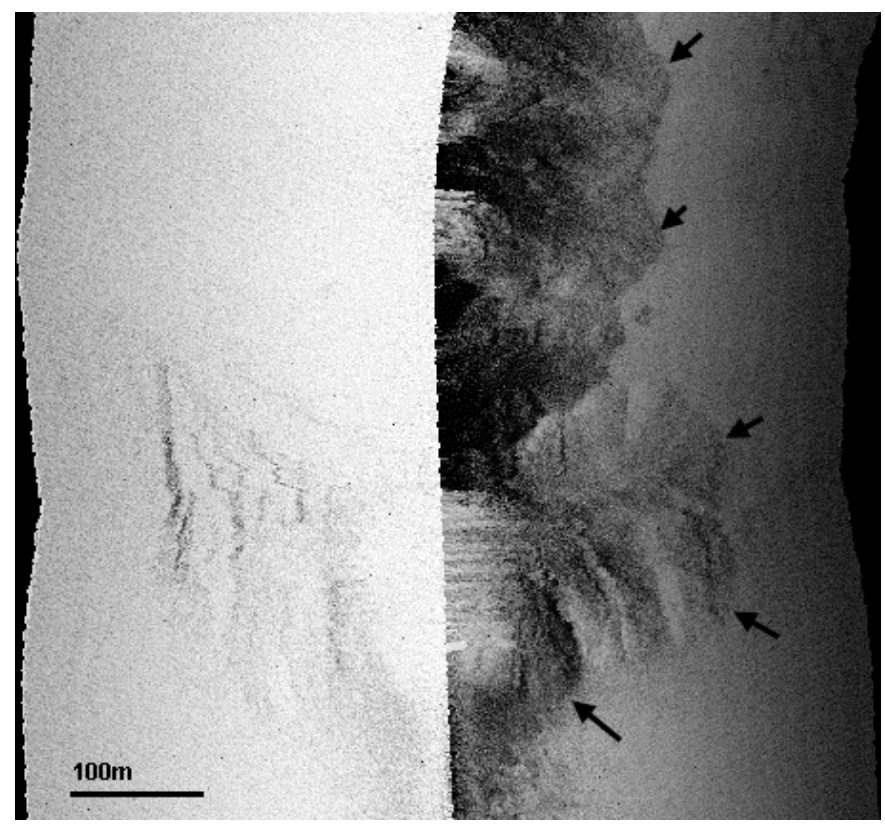

Fig. 1. Edge of canyons on the shelf break (Thyrrenian Sea). The left side of the sonographs has very low levels of backscatter due to the high steepness of the bottom. The sonographs follows the shelf break, the continental shelf is tow ard the right.

- Confined seafloor morphologies, such as gullies and channels (i.e. gateways and channels - Fig. 2).

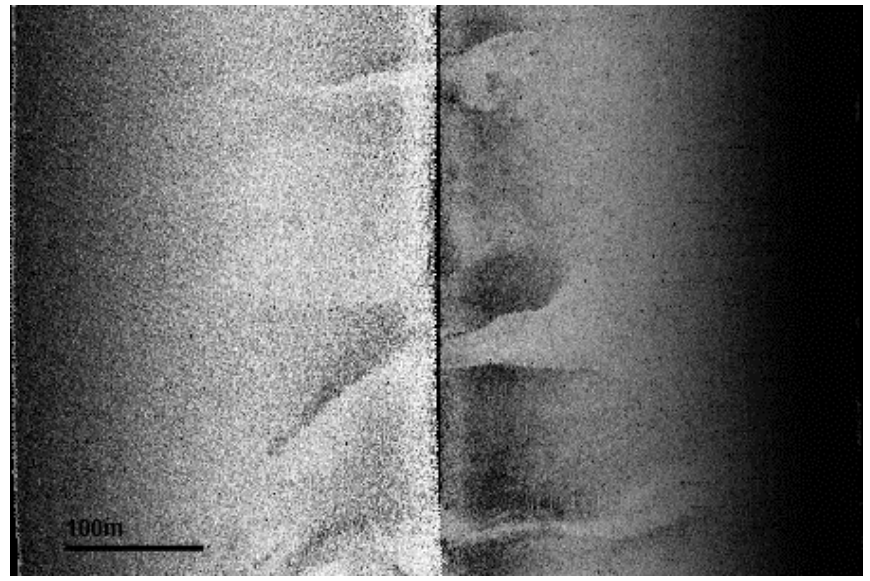

Fig. 2. Confined erosional bedforms on the shelf break (Thyrrenian Sea). The continental shelf is tow ard the right. 
- $\quad$ Erosive seafloor features related to bottom current e.g. scours, furrows etc. (Fig. 3).

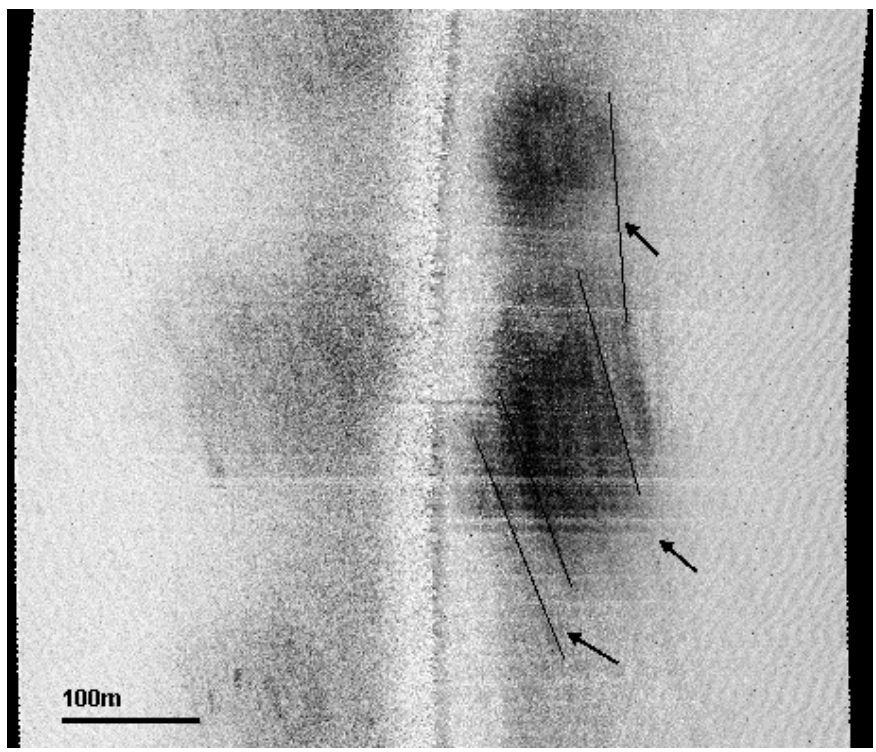

Fig. 3. Furrows (highlighted by straight black lines) and patches of coarse grained sediment (rounded areas with high levels of quite homogeneous backscatter). Thyrrenian Sea, continental shelf, $40 \mathrm{~m}$ of water depth.

- $\quad$ Positive reliefs of biogenic origin (carbonate mounds, carbonate build-ups etc. Fig. 4).

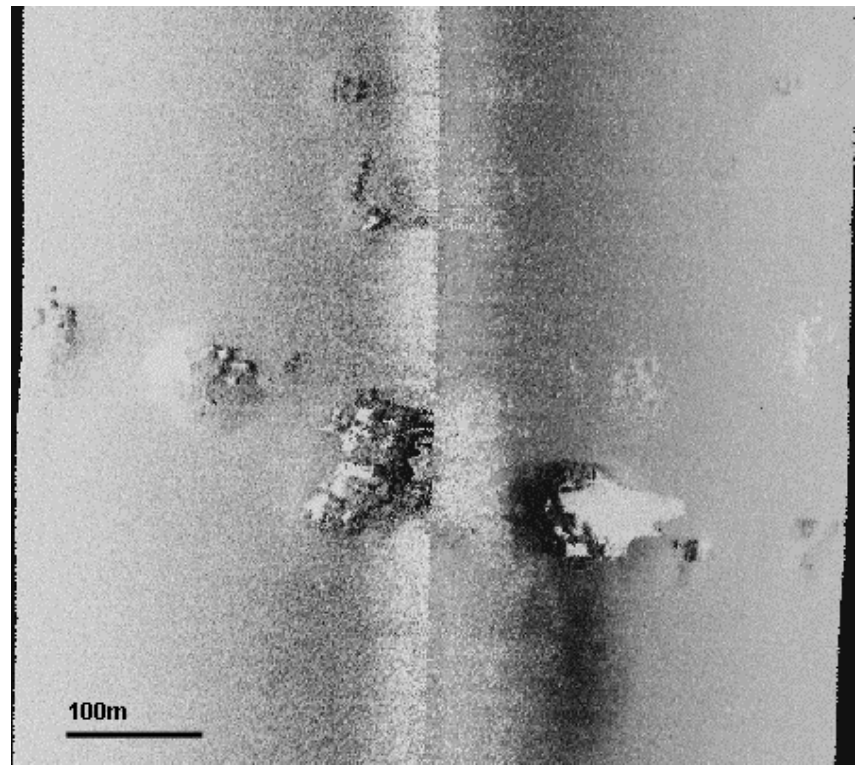

Fig. 4. Positive reliefs on the seafloor (Thyrrenian Sea $-80 \mathrm{~m}$ of water depth). 
- Mud volcanoes and pockmarks, methane-derived carbonate heterogeneous crusts and slabs, carbonate build-ups associated with seepage (Fig. 5).

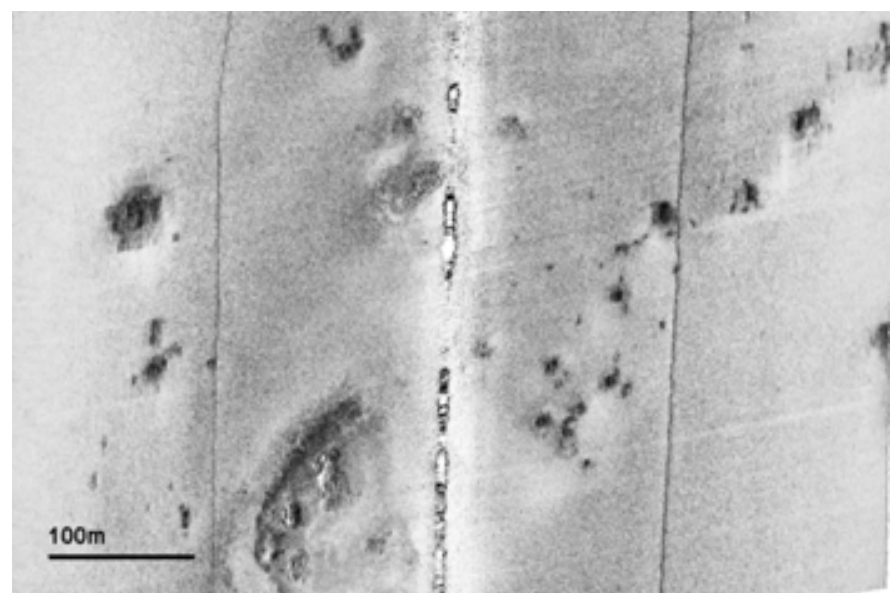

Fig. 5. Small mud volcanoes and seepage-related seafloor features (Sicily channel - $160 \mathrm{~m}$ of water depth).

- Sedimentary structures: from small to large dunes in their different morphologies (barchan dunes, lunate dunes etc. Fig. 6), sediment waves of metric scales, gravel/ sand bars, irregular gravel/ sand patches (Fig. 3), sand/ gravel ribbons, obstacles and scours (comet marks) etc.

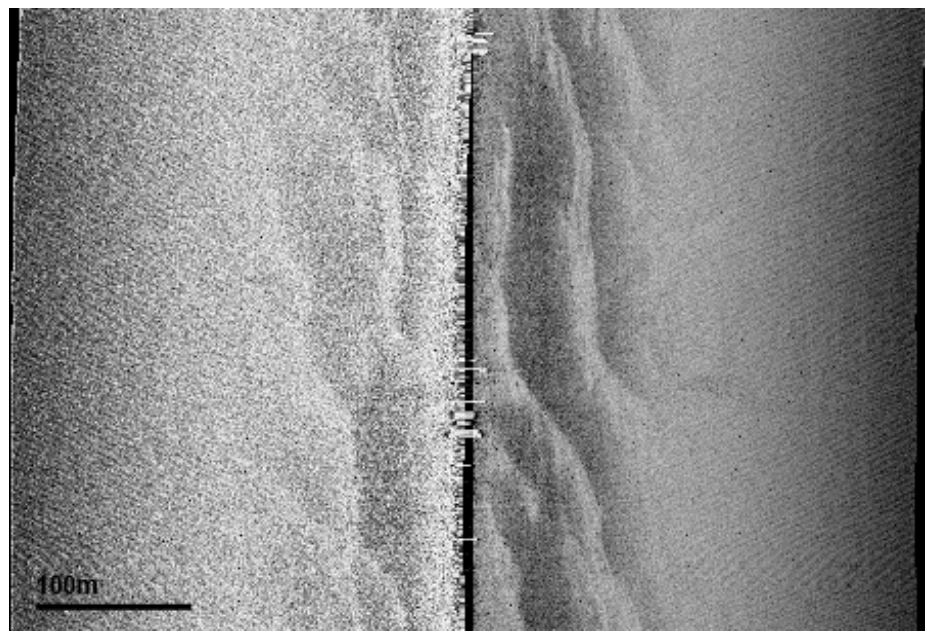

Fig. 6. Depositional bedforms on the outer continental shelf (Thyrrenian Sea - 80m of water depth).

- Failure-related seafloor features, such as blocks of detached sediment, pressure ridges, tension cracks (Fig. 7) etc. 


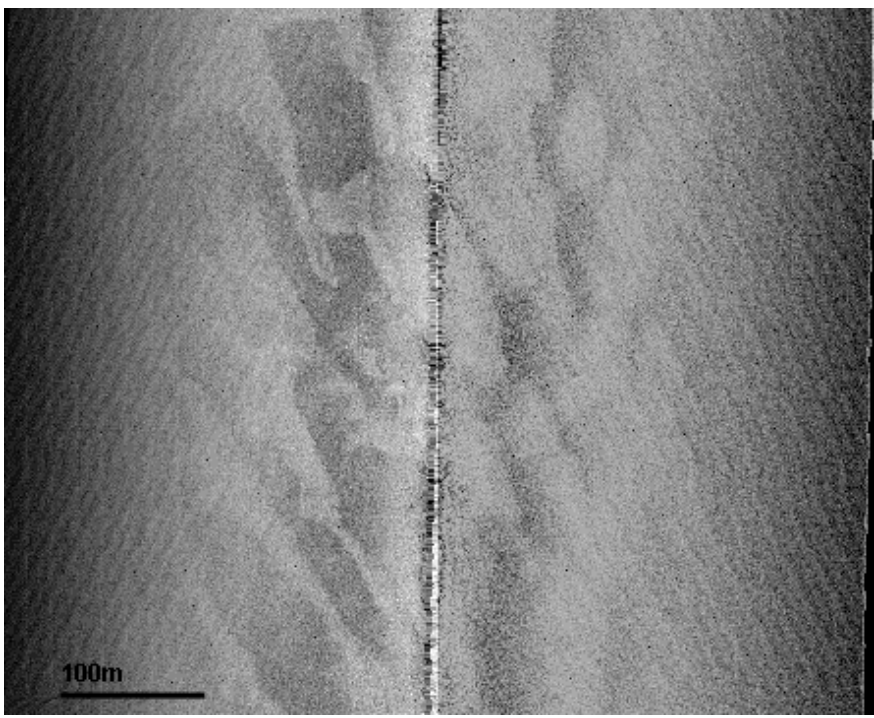

Fig. 7. Depositional bedforms on the outer continental shelf (Thyrrenian Sea - 60m of water depth).

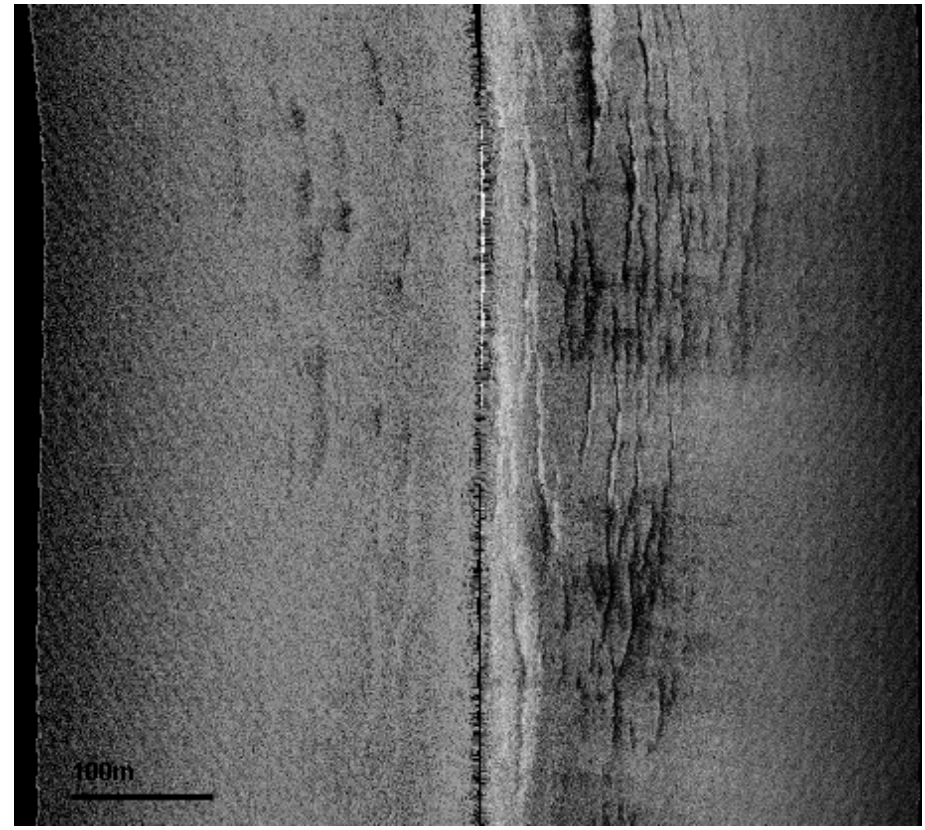

Fig. 8. Fractures on the seafloor (Thyrrenian Sea - 180m of water depth). The sonographs run parallel to the shelf break, the orientation of the fractures suggests a possible inception of mass-wasting, probably due to seabed creeping. 


\subsection{High frequency SSS imagery through medium-range setting}

SSS surveys through a medium-range setting aim to cover relatively wide areas of the seafloor on the continental shelf. Range between 150 and $300 \mathrm{~m}$ are considered. The sonograph's resolution can be less than $1 \mathrm{~m}$ per pixel. SSS sonographs of medium-range setting produce medium-scale maps of the seafloor to image the local geological/ geomorphological attributes of the investigated areas. Indeed the medium-range setting is relevant for mapping seafloor morphologies and sediment characteristics of the whole continental shelf, from roughly $20 \mathrm{~m}$ of water depth down to the shelf break. It is worth considering that seafloor mapping at meso-scales is important because many of the solutions to environmental problems (from geo-hazards to offshore resources management) require changes in management strategies at this 'seascape scale'. In addition, backscattering data along with bathymetry at meso-scale provide a basis for integrating seabed samples and biological information from which habitat may be interpreted (Kenny et al., 2003). Standards and protocols for habitat mapping are starting to emerge at international level (see MESH EU-project - http:/ / www.searchmesh.net) and they strongly consider that backscattering information from multibeam data or SSS sonographs provide the crucial spatial and structural context for more detailed investigation which can reveal the benthic ecology. Therefore, marine habitat maps are usually based on a combination of wide-area data sets (e.g. side-scan sonar data), able to illustrate the abiotic environment, and point- or line-based information (e.g. photo and video data, seabed samples) providing 'groundtruthing' of the substrate and biological information.

On the Mediterranean continental shelves, the phanerogam biocenosis are well detectable on medium-range SSS sonographs, along with most of their physiographic attributes, that can be relevant to assess their health state (Figs. 9, 10, 11 and 12).
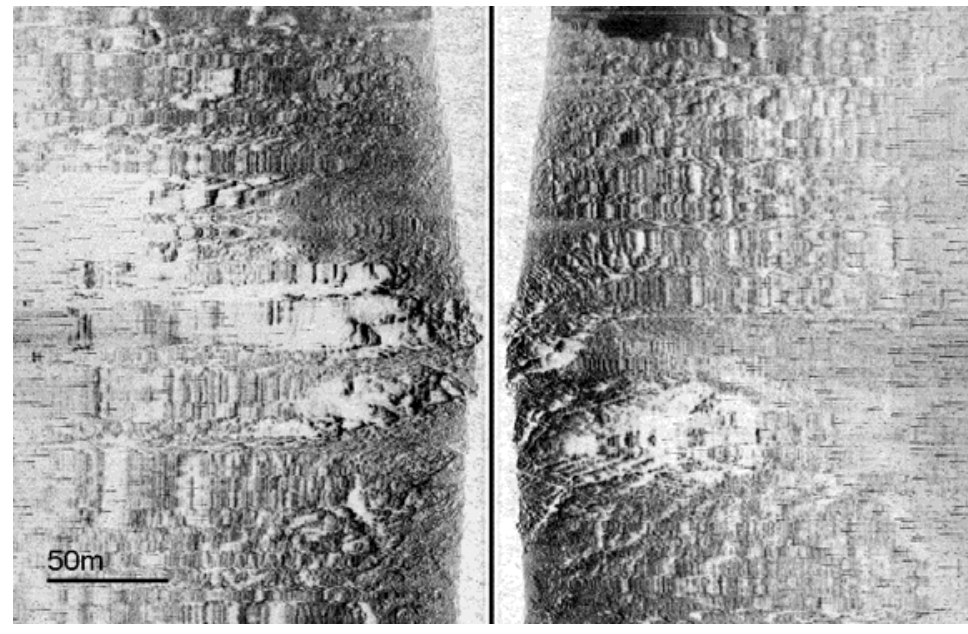

Fig. 9. Posidonia oceanica on rocky substrate. See at the centre of the sonograph the short distance recorded between the tow fish and the bottom and the prominent shadows that the rocky outcrops create on the left channel. 

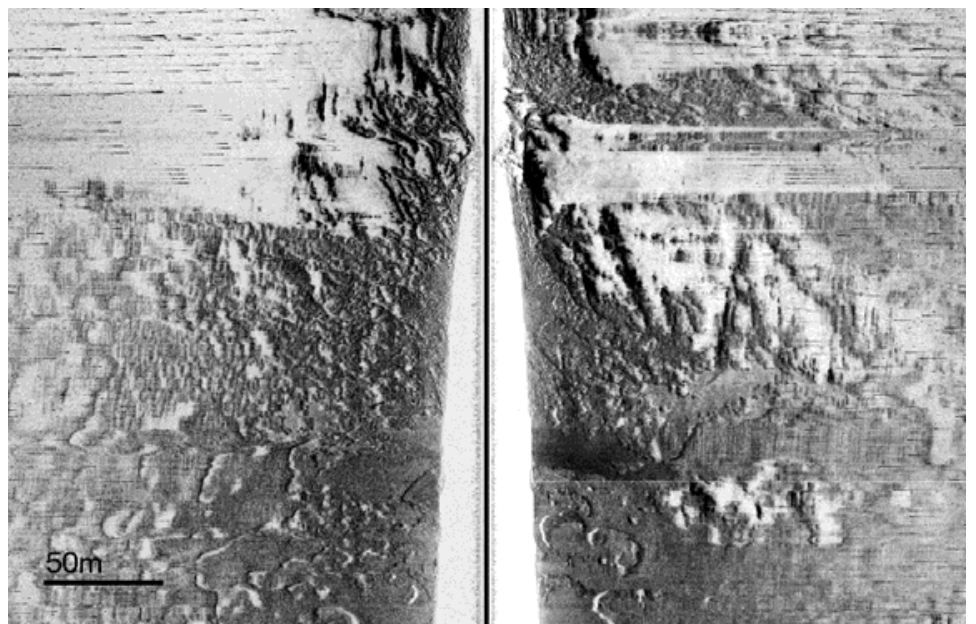

Fig. 10. Passage from Posidonia oceanica on rocky substrate (upper part of the sonograph, where prominent shadows occur on both the channels) to Posidonia oceanica on matte (middle part of the sonograph) and to degraded matte of Posidonia oceanica with marked intramattes and erosive features (lower part of the sonograph, especially on the left channel).

Geological attributes that can be imaged with medium-range SSS sonographs are:

- Rocky outcrops where sub-metric fractures and other structural features can also be detected (Figs. 12, 13 and 14).
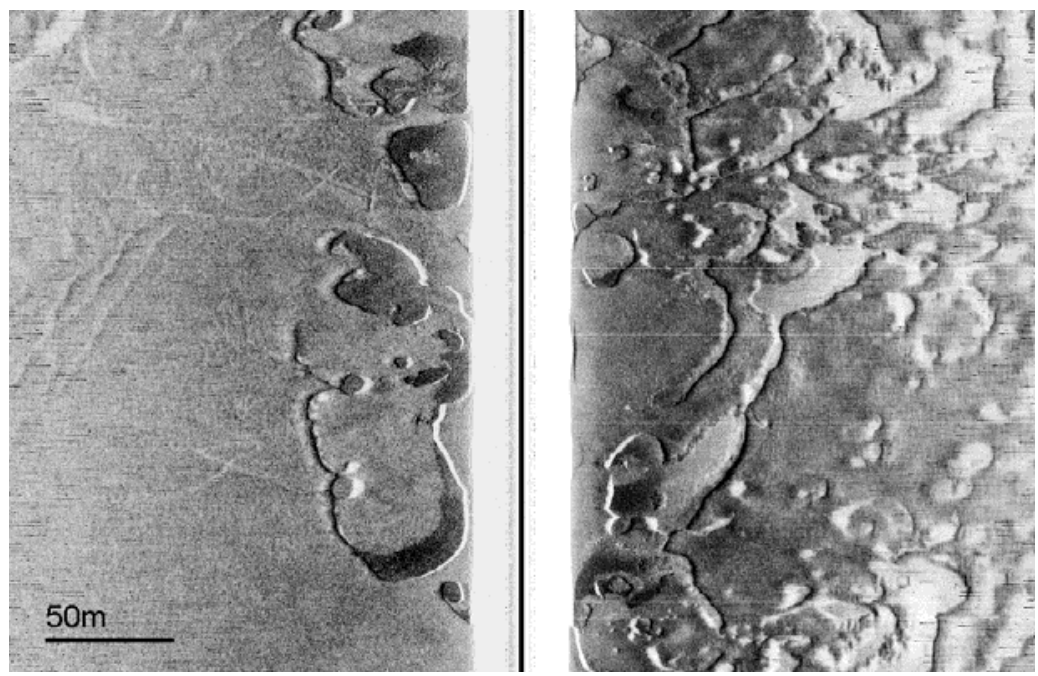

Fig. 11. Dead and degraded matte of Posidonia oceanica, that appears nearly compact on the left channel and highly affected by strong erosion on the right. 


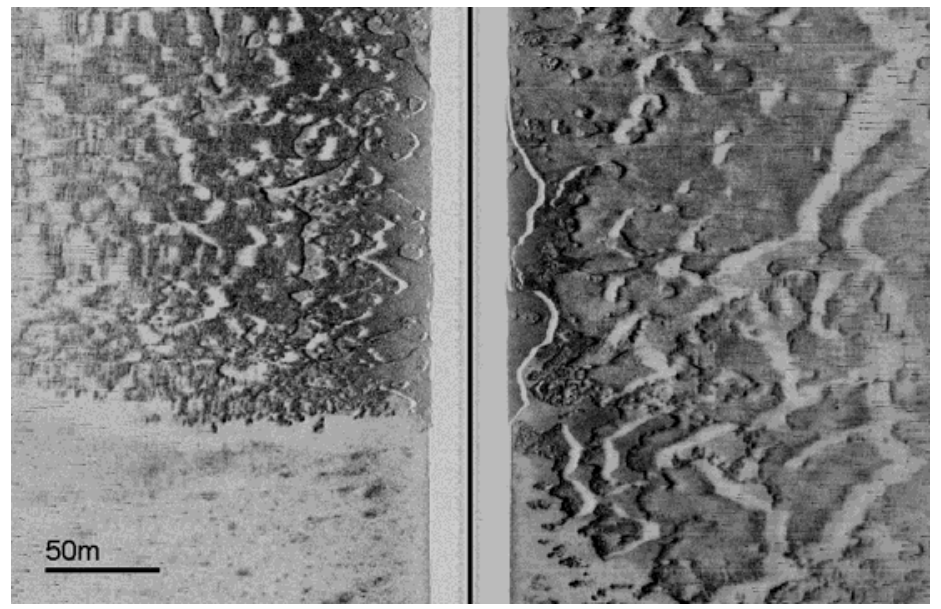

Fig. 12. Upper limit of degraded matte of Posidonia oceanica where erosional features are dominant.
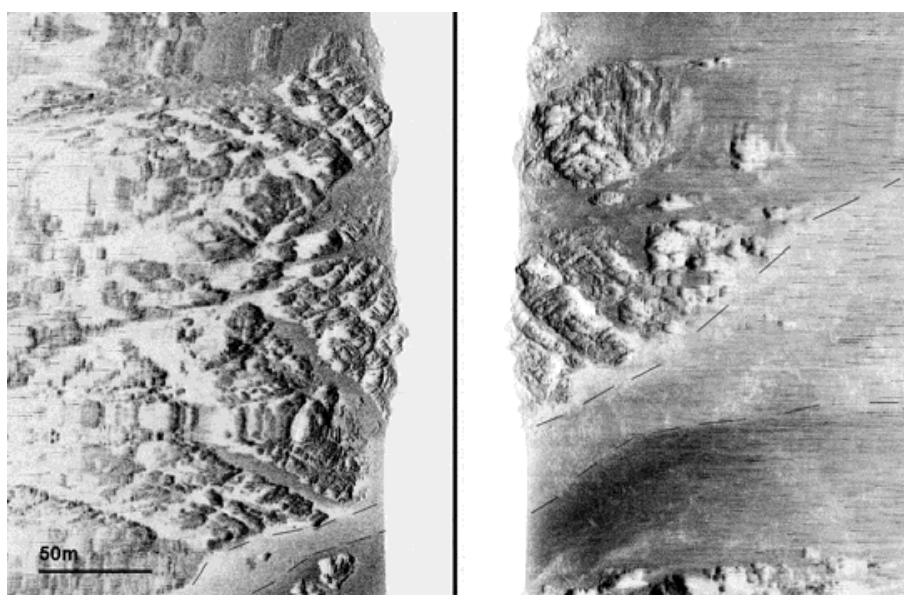

Fig. 13. Rocky outcrops where the orientation of structural lineaments, which consist of perpendicular fractures, are clearly imaged. 

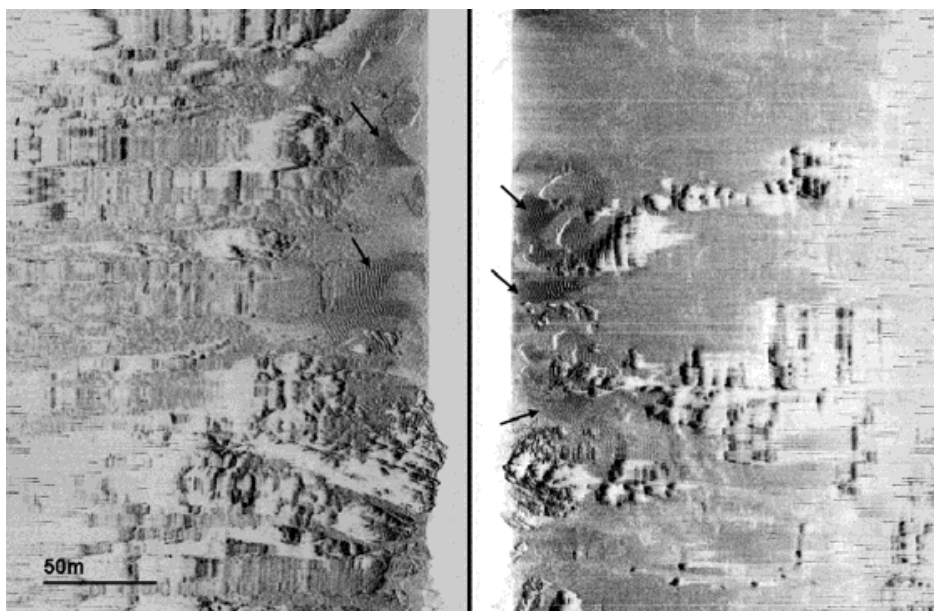

Fig. 14. Rocky outcrops and sediment. Arrows indicate well defined areas made by coarse sediment with ripples.

- $\quad$ Erosive features of sub-metric scales: scours, furrows etc.

- Positive reliefs of biogenic origin (e.g. biogenic formations made by coralline algae).

- Small scale mud volcanoes and pockmarks, methane-derived carbonate heterogeneous crusts and slabs, carbonate build-ups associated with seepage (Figs. 15 and 16).

- Sedimentary structures: small dunes in their different morphologies (barchan dunes, lunate dunes etc.), sediment waves, ripples, gravel/ sand bars, irregular gravel/ sand patches, sand/ gravel ribbons, surface lineations, obstacles and scours (comet marks) etc. (Fig. 13).

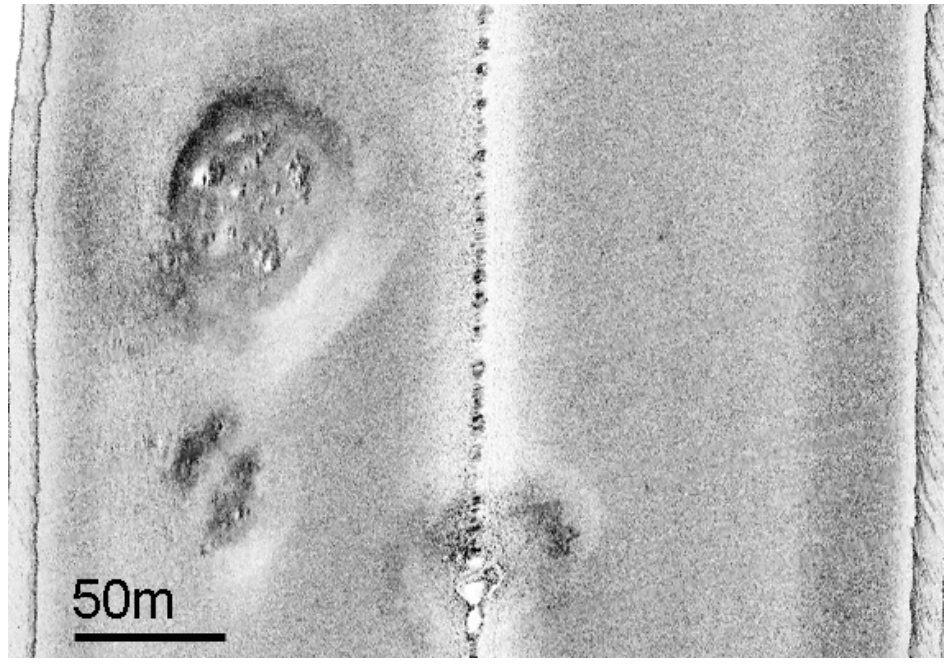

Fig. 15. Small sub-circular mud volcanoes (Savini et al., 2009). See at the top the backscatter associated to the occurrence of methane-derived carbonate crusts. 


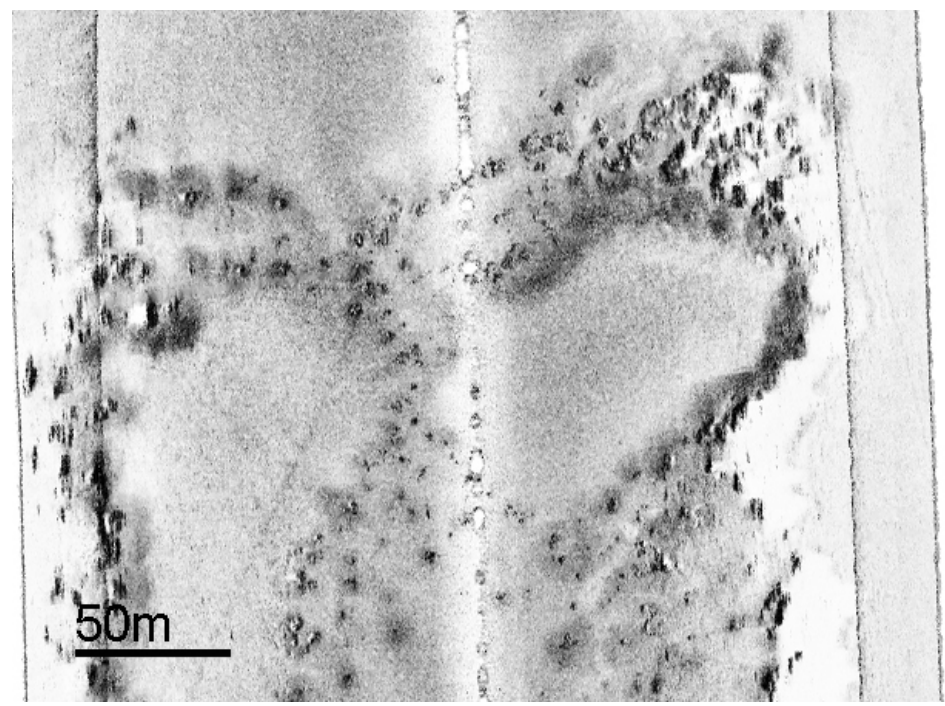

Fig. 16. Hard substrata made by methane-derived carbonate build-ups.

\subsection{High frequency SSS imagery through small-range setting}

Range between a few metres and $100 \mathrm{~m}$ are considered. SSS surveys conducted using a small-range setting are used in shallow water and provide high resolution sonographs. Often a high resolution setting of the SSS system is needed in a survey which aims to search for specific targets, such as small shipwrecks and other small-scale objects, or to monitor underwater pipelines. In optimal conditions, sonograph resolution can be less than $10 \mathrm{~cm}$ per pixel.

Operating with small-scale range, the transducer has to keep a short distance from the seafloor (a few metres), so that its safety is not compromised by articulated topography with pinnacles and/ or local rocky outcrops, even if a fast recovery of the tow fish is allowed by the shallow water (because of the few metres of cable out).

While habitat mapping is mainly performed through medium-range SSS surveys, a smallrange setting in a SSS survey can provide remote data useful for further habitat characterization. For instance, within the Mediterranean setting, meadows of Posidonia oceanica (which represent benthic habitat of conservation value, listed in the EC Habitats Directive due to its high level of biological diversity) can be imaged in detail by small-range sonographs, since most of their physiographic attributes and ecological descriptors (i.e. upper and lower depth limit of the meadow, density, bottom cover, structure of the matte, occurrence of intramattes and other erosive features, characterization of the substrate, identification of dead or highly degraded matte, human impact due to anchoring and fishery) are at metric and sub-metric scale and are well imaged through SSS sonographs acquired with small-range settings (Figs. 17, 18, 19, 20 and 21). 
Side-Scan Sonar as a Tool for Seafloor Imagery:

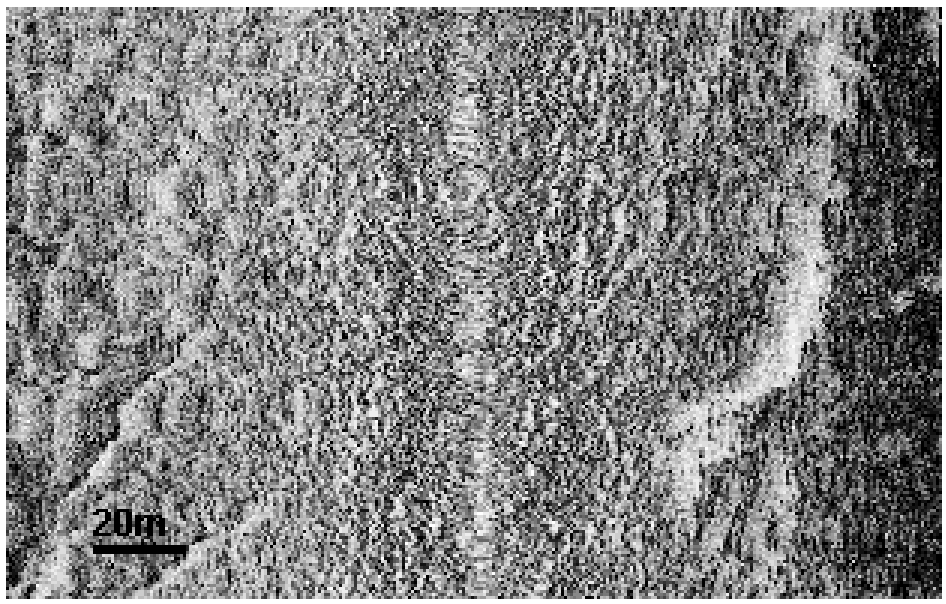

Fig. 17. Posidonia oceanica on matte.

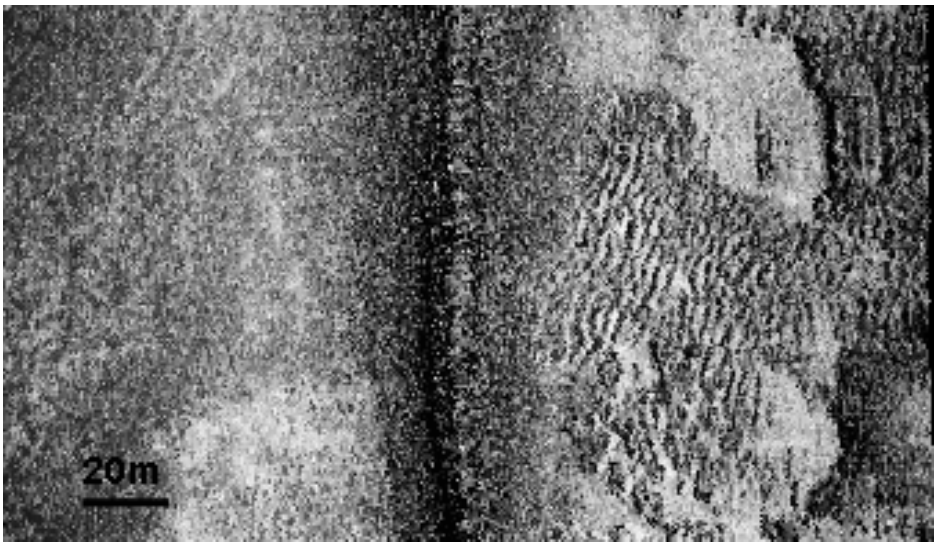

Fig. 18. Passage from Posidonia oceanica on matte (on the right channel) to dead/ degraded matte of Posidonia oceanica. 


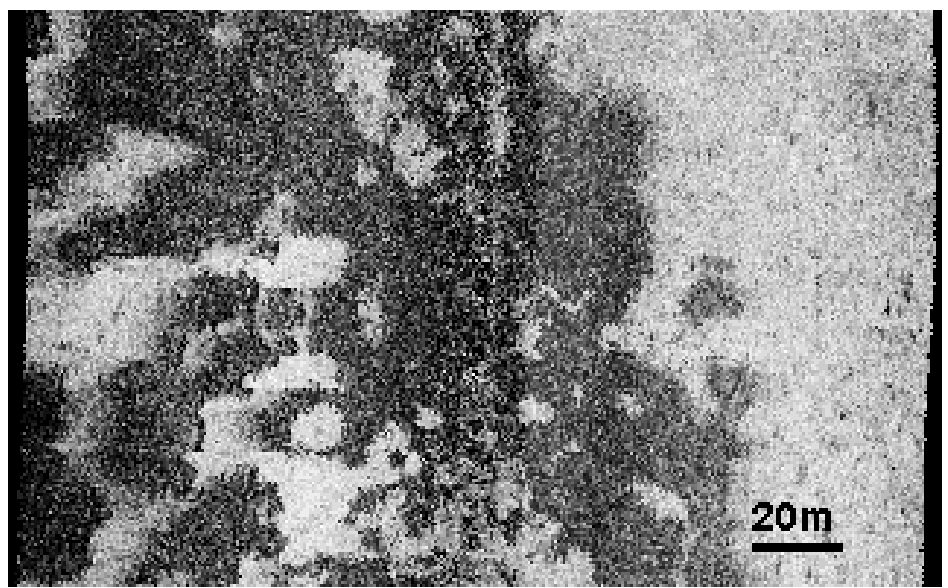

Fig. 19. Meadows of Cymodocea nodosa (high backscatter).

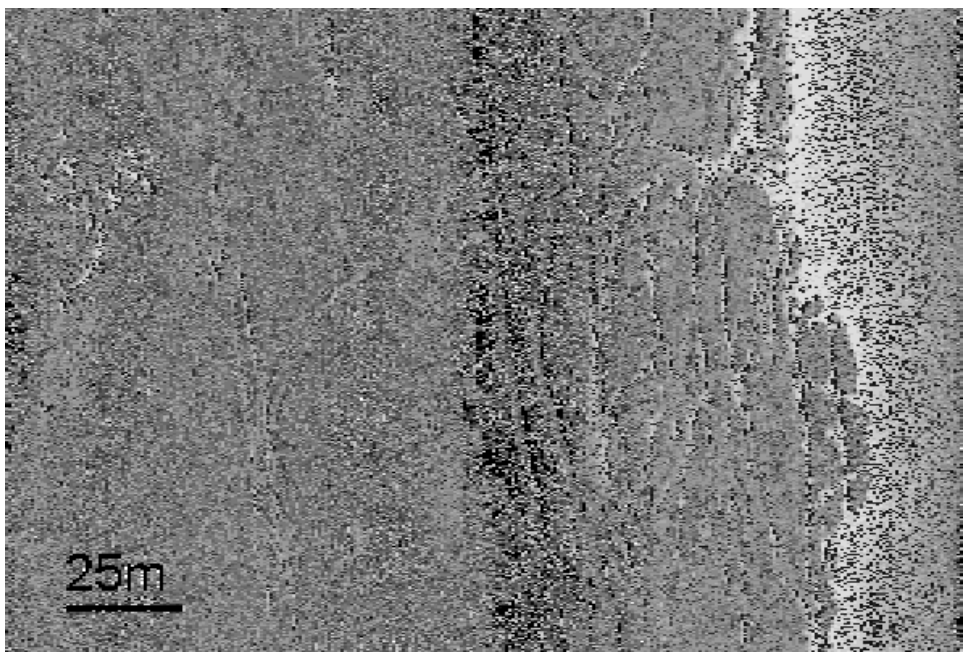

Fig. 20. Prominent track left on the matte of Posidonia oceanica by anchoring operations. 


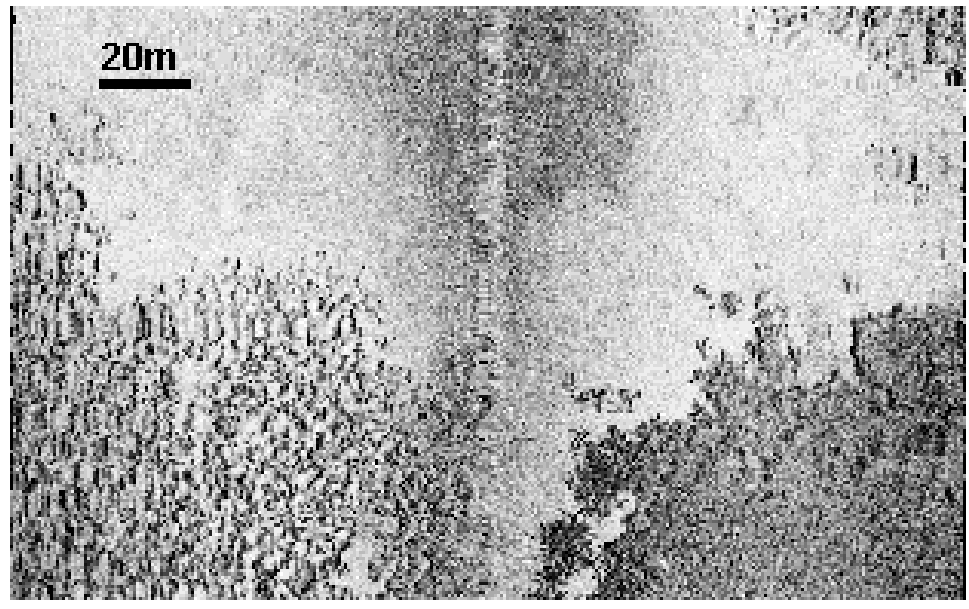

Fig. 21. Posidonia oceanica on sediment (on the left channel, lower part), Cymodocea nodosa (right channel lower part) and sediment.

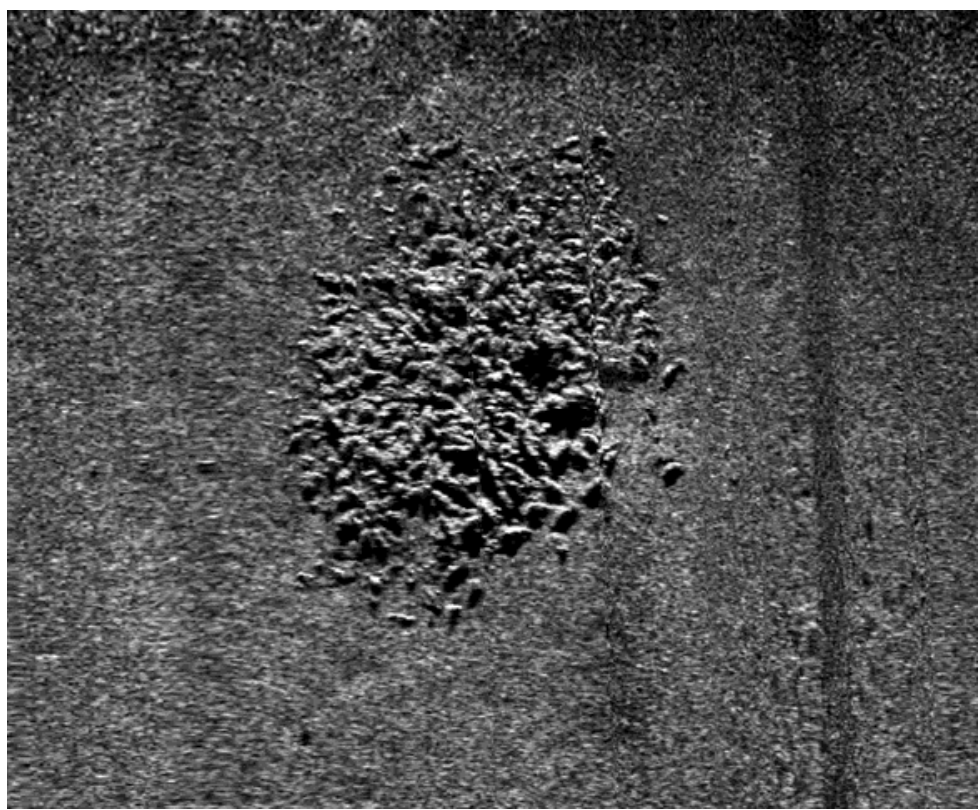

Fig. 22. Amphora on the seafloor (Savini and Petrillo, 2009). Each one is 1,3m in length.

Geological attributes that can be well imaged on small-range SSS sonographs are mostly related to small scale sedimentary structures (such as ripples and surface lineations at the centimetric scale, small comet marks etc.) and erosional bottom current related bedforms (e.g. small scours and furrows). However, as stated above, small-range SSS surveys are generally carried out to investigate/ image small targets on the seafloor (Fig. 22). 


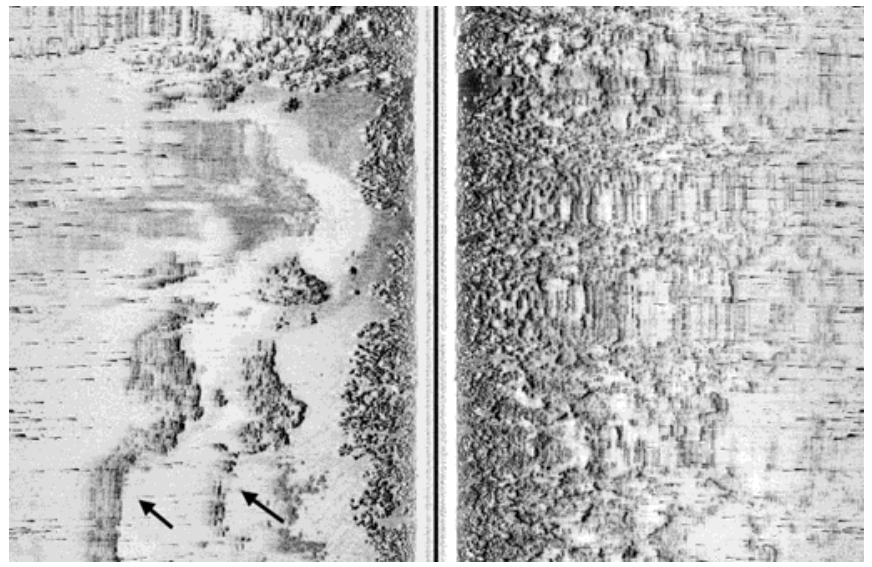

Fig. 22. Multiple (black arrows) on the left channel.

\subsection{Peculiar SSS images}

Here after are some peculiar situations that can occur during a side-scan sonar survey. Such situations occur in sonographs affected by noise that comes from the underwater environment (e.g. signals generated from other ships' propellers and/ or from interference with other acoustic sources, artefacts created by objects or fishes in the water column) and particular objects/ infrastructures mapped on the seafloor.

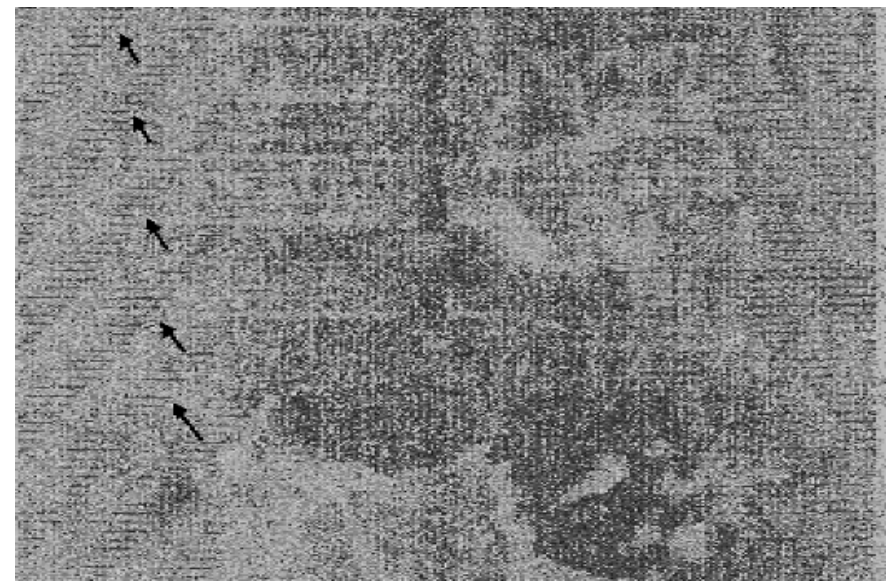

Fig. 23. Noise on the sonograph (black arrows) produced by interference with other acoustic source (in this case a single beam echosounder). 


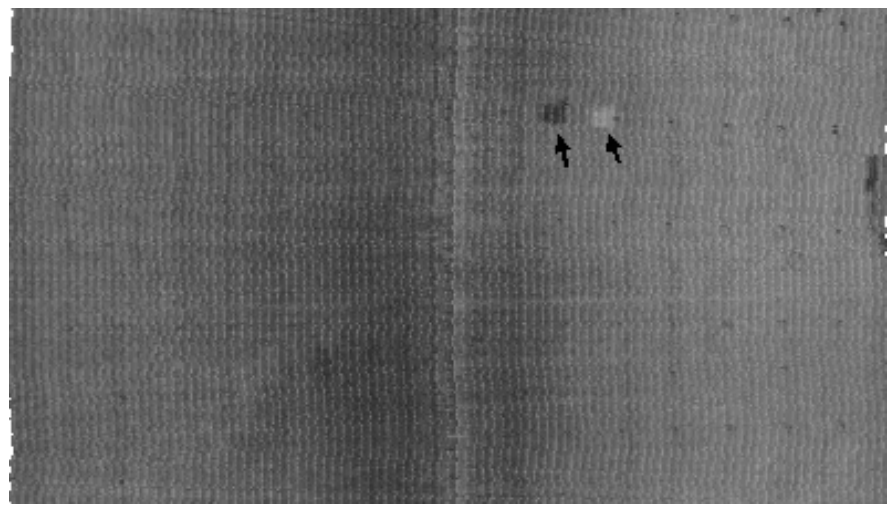

Fig. 24. A shoal of fish and its associated shadows, which appear separated on the sonograph because of the position of the shoal in the water column.
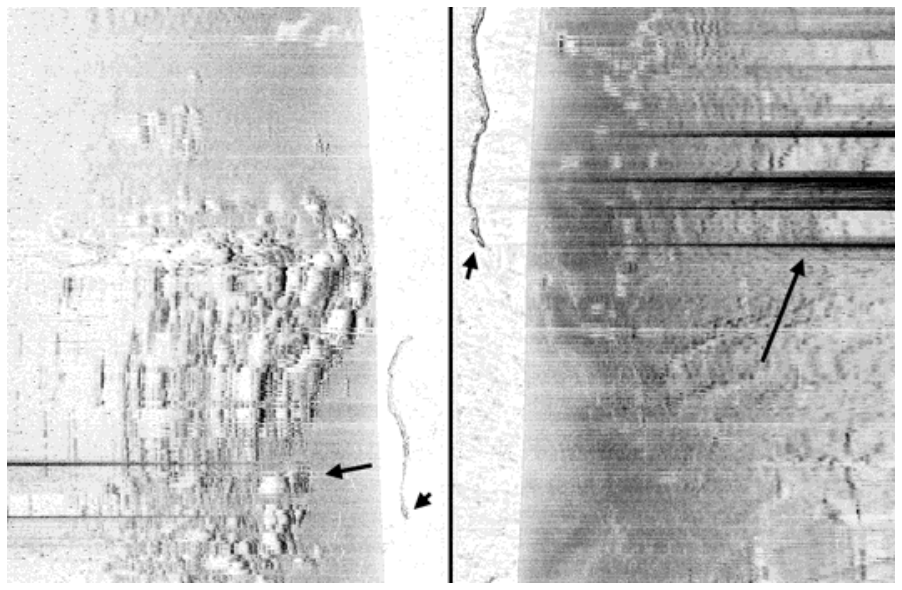

Fig. 25. Noise on the sonograph that is produced by the engine of another ship. The wake of the ship also leaves a typical noise in the water column (central part of the sonograph). 


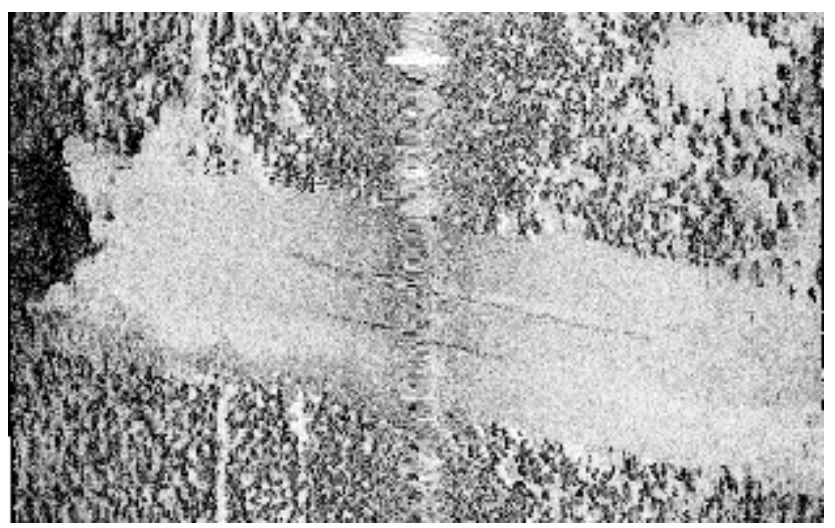

Fig. 26. Meadow of Posidonia oceanica interrupted by sediment where some parts of two pipelines are visible.

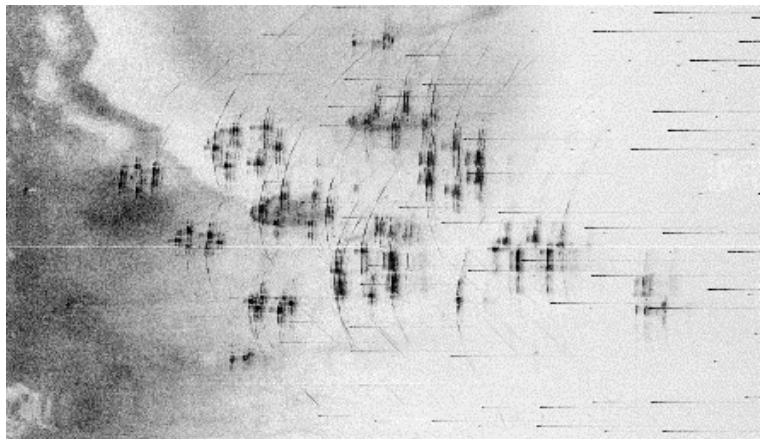

Fig. 27. Fish aquaculture.

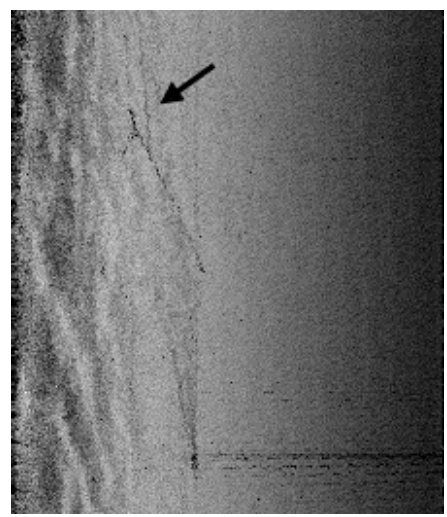

Fig. 28. Fishing net 'at work' on the seafloor. Note the two gears which keep open the net and the noise of the engine of the fishing boat (lower part on the right). 


\section{Conclusion}

This chapter aimed to provide a useful reference document representing important seafloor features and sediment characteristics on continental shelf in the Mediterranean setting. Indeed there is an exhaustive literature dealing with theoretical issues concerning SSS functioning and data processing (Fish and Carr, 1999; Blondel and Murton, 1997) and there are also some published books that can support sonograph interpretation within the oceanic environment (e.g. Blondel, 2009). Nevertheless a number of peculiar seafloor features of the Mediterranean continental shelf, often monitored in many surveys, are not so well known from literature, in terms of their peculiar acoustic backscattering. This chapter aimed to offer a reference that can help in recognising the most significant seafloor features that characterise the Mediterranean continental shelves on SSS sonographs.

\section{Acknowledgements}

This chapter benefited from funding through the 2000-2001 Italian MIUR programme 'founding for young researchers' (ministry advise n. 1707, 22.07.1998 ), by which the author was coordinator of the project 'Atlas of side-scan sonar sonographs: the acoustic response of the different geomorphological features that characterize the Mediterranean continental shelf. The author is also grateful to captains, crew and all colleagues (among other Lidia Olivieri, Andrea Grazzini, Paolo Orrù and Tommaso Granata) met during the numerous activities carried out at sea.

\section{References}

Belderson, R.H., Kenyon, N.H., Stride, A.H. and Stubbs, A.R., (1972). Sonographs of the Sea Floor. Elsevier, Amsterdam, 185 p.

Blondel, P. and Murton, B.J., (1997). Handbook of Seafloor Sonar Imagery. Chichester. John Wiley and Sons.

Blondel, P., (2009). The Handbook of Side-scan Sonar. Springer Verlag

Blondel, P., Parson, L.M. Robigou, V., (1998). “TexAn: Textural Analysis of Side-scan Sonar Imagery and Generic Seafloor Characterisation." Proceedings of Oceans '98 vol. 2: 419-423.

Boyle, F.A. and Chatiros, N.P., (1995). A model for acoustic backscatter from muddy sediments. eburnal of the Acoustical Society of America '98(1), 525-530.

Cochrane, G.R. and Lafferty, K.D., 2002. "Use of acoustic classification of side-scan sonar data for mapping benthic habitat in the Northern Channel Islands, California." Continental Shelf Research 22: 683-690.

Damuth, J.E., (1980). "Use of high frequency (3.5 - $12 \mathrm{kHz})$ echograms in the study of near bottom sedimentation processes in the deep sea." Marine Geology 38: 51-75.

Fish, J.P. and Carr, H.A., (1990). Sound underwater images. A guide to the generation and interpretation of side-scan sonar data. Orleans (Low er Cape Publishing), 188 p.

Fleming, B.W., (1976). "Side Scan Sonar: A Practical Guide," International Hydrographic Review, Vol.1 III, No. 1 (January 1976).

Flood, R.D., (1980). "Deep-sea sedimentary morphology: modeling and interpretation of echo-sounding profiles." Mar. Geol., 38: 77--92. 
Goff, J.A., Olson, H.C., Duncan, C.S., 2000. "Correlation of side-scan backscatter intensity with grain size distribution of shelf sediments, New Jersey margin." Geo Mar. Lett. $20,43-49$.

Holland, C. W., Hollett R. and Troiano L., (2000). "Measurement technique for bottom scattering in shallow water," I Acoust. Soc. Am. 108, 997-1011.

Huvenne, V.A.I., Blondel, Ph., Henriet, J.-P., 2002. "Textural analyses of side-scan sonar imagery from two mound provinces in the Porcupine Seabight." Mar. Geol. 189, $323-341$.

Jackson, D.R. and Briggs K.B., (1992). "High frequency bottom backscattering: roughness versus sediment volume backscattering." d Acous Soc. Am. 92: 962-977.

Jones E.J.W., (1999). Marine Geophysics. Wiley.

Kenny, AJ, Cato, I, Desprez, M, Fader, G, Schuttenhelm, R.T.E. and Side, J., (2003). “An overview of seabed-mapping technologies in the context of marine habitat classification." ICES eburnal of Marine Science 60:411-418.

Lo Iacono, C., Gràcia, E., Diez, S., Bozzano, G., Moreno, X., Dañobeitia, J. and Alonso, B., (2008). "Seafloor characterization and backscatter variability of the Almería Margin (Alboran Sea, SW Mediterranean) based on high-resolution acoustic data." Marine Geology 250 (2008) 1-18.

McQuillin, R. and Ardus, D.A., (1977). Exploring the geology of shelf seas. Graham \& Trotman (London), $234 \mathrm{p}$.

Medwin, H. and Blue, J. E., (2005). Sounds in the sea: from ocean acoustics to acoustical oceanography. Cambridge University Press.

Medwin, H. and Clay, C. S., (1998). Fundamentals of acoustical oceanography. Applications of modern acoustics. Academic Press

Morang, A., Larson, R. and Gorman, L., (1997). "Monitoring the Coastal Environment, Part III, Geophysical and Research Methods.” eburnal of Coastal Research, 13, 1064-1085.

Savini, A. (2004). "Metodologie di analisi di prospezioni geofisiche in ambiente marino e loro implementazione in applicazioni S.I.T.”. $P h D$ Thesis, Milano-Bicocca University.

Savini A., Malinverno E., Etiope G., Tessarolo C., Corselli C. (2009). "Shallow seep-related seafloor features along the Malta Plateau (Sicily channel -Mediterranean Sea): Morphologies and geo-environmental control of their distribution". Marine and Petroleum Geology 26, 1831-1848.

Savini A., Petrillo M. (2009). "Seascapes of war: investigations with marine geophysics". Europe's Deadly Century - Perspectives on 20th century conflict heritage. Edited by Neil Forbes, Robin Page and Guillermo Pèrez. Published by English Heritage. 


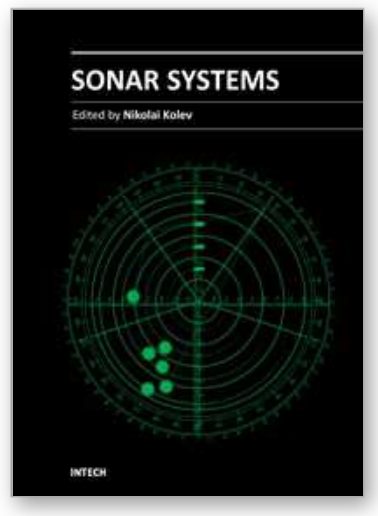

\author{
Sonar Systems \\ Edited by Prof. Nikolai Kolev
}

ISBN 978-953-307-345-3

Hard cover, 322 pages

Publisher InTech

Published online 12, September, 2011

Published in print edition September, 2011

The book is an edited collection of research articles covering the current state of sonar systems, the signal processing methods and their applications prepared by experts in the field. The first section is dedicated to the theory and applications of innovative synthetic aperture, interferometric, multistatic sonars and modeling and simulation. Special section in the book is dedicated to sonar signal processing methods covering: passive sonar array beamforming, direction of arrival estimation, signal detection and classification using DEMON and LOFAR principles, adaptive matched field signal processing. The image processing techniques include: image denoising, detection and classification of artificial mine like objects and application of hidden Markov model and artificial neural networks for signal classification. The biology applications include the analysis of biosonar capabilities and underwater sound influence on human hearing. The marine science applications include fish species target strength modeling, identification and discrimination from bottom scattering and pelagic biomass neural network estimation methods. Marine geology has place in the book with geomorphological parameters estimation from side scan sonar images. The book will be interesting not only for specialists in the area but also for readers as a guide in sonar systems principles of operation, signal processing methods and marine applications.

\title{
How to reference
}

In order to correctly reference this scholarly work, feel free to copy and paste the following:

Alessandra Savini (2011). Side-Scan Sonar as a Tool for Seafloor Imagery: Examples from the Mediterranean Continental Margin, Sonar Systems, Prof. Nikolai Kolev (Ed.), ISBN: 978-953-307-345-3, InTech, Available from: http://www.intechopen.com/books/sonar-systems/side-scan-sonar-as-a-tool-for-seafloor-imageryexamples-from-the-mediterranean-continental-margin

\section{INTECH}

open science | open minds

\author{
InTech Europe \\ University Campus STeP Ri \\ Slavka Krautzeka 83/A \\ 51000 Rijeka, Croatia \\ Phone: +385 (51) 770447 \\ Fax: +385 (51) 686166 \\ www.intechopen.com
}

\author{
InTech China \\ Unit 405, Office Block, Hotel Equatorial Shanghai \\ No.65, Yan An Road (West), Shanghai, 200040, China \\ 中国上海市延安西路65号上海国际贵都大饭店办公楼 405 单元 \\ Phone: +86-21-62489820 \\ Fax: $+86-21-62489821$
}


(C) 2011 The Author(s). Licensee IntechOpen. This chapter is distributed under the terms of the Creative Commons Attribution-NonCommercialShareAlike-3.0 License, which permits use, distribution and reproduction for non-commercial purposes, provided the original is properly cited and derivative works building on this content are distributed under the same license. 